\title{
BENTUK FATIS BAHASA SASAK
}

\section{PHATIC COMMUNICATION IN SASAK}

\author{
Hilmiati \\ PGMI IAIN Mataram \\ hilmiatibadrin@yahoo.co.id \\ Tanggal naskah masuk: 6 Agustus 2012 \\ Tanggal revisi terakhir: 30 November 2012
}

\begin{abstract}
The title of this research is Phatic Communicatio in Sasak. This research is aimed at explaining phatic communication among Sasak speakers. Qualitative and empiric approach are used to describe the meaning of phatic communication used by native speakers of Sasak. Informants are chosen among Sasak community of the same dialect, namely ngeno-ngene dialect in Bagik Papan Village. Thus, the three qualitative methods - interview, transcription, and textual analysis - are applied in this study. The data is collected through in depth interview and exploration technique. It is found that phatic communication among Sasak speakers is relevant and suitable to the Malinowski's theory of phatic communication and Halliday's theory of interpersonal language function.
\end{abstract}

Key words : Form and Function phatic, Sasak, ngeno ngene dialect, Bagik Papan village

\section{Abstrak}

Penelitian ini berjudul Bentuk Fatis dalam Bahasa Sasak. Penelitian ini bertujuan untuk menjelaskan bentuk fatis oleh penutur bahasa Sasak. Penelitian ini menggunakan pendekatan qualitatif dan empiris untuk mengkaji makna bentuk fatis yang digunakan oleh penutur asli bahasa Sasak. Informan dipilih dari penutur bahasa Sasak dialek ngeno-ngene di desa Bagik Papan. Selanjutnya, dalam penelitian ini digunakan metode qualitatif yang meliputi wawancara, transkripsi, dan analisis teks. Pengumpulan data dilakukan dengan teknik wawancara mendalam dan eksplorasi. Hasil penelitian menunjukkan bahwa bentuk fatis dalam penutur bahasa sasak relevan dan sesuai dengan teori tentang komunikasi fatis oleh Malinowski dan teori fungsi bahasa interpersonal oleh Halliday.

Kata kunci: Bentuk dan Fungsi fatis, bahasa Sasak, dialek ngeno ngene, Desa Bagik Papan

\section{PENDAHULUAN}

Bahasa merupakan alat yang paling penting dalam berkomunikasi. Pentingnya bahasa sebagai alat komunikasi dapat dilihat dari setiap aktivitas manusia selalu menggunakan bahasa sebagai wahana pokoknya. Bahasa adalah suatu sistem lambang berupa bunyi, bersifat arbitrer, digunakan oleh suatu masyarakat tutur untuk bekerjasama, berkomunikasi, dan mengidentifikasi diri. Sebagai sebuah sistem, maka bahasa terbentuk oleh suatu aturan, kaidah atau pola-pola tertentu, baik dalam tata bunyi, tata bentuk, maupun tata kalimat. Bila aturan, kaidah, atau pola ini dilanggar, maka komunikasi dapat terganggu. 
Betapa pentingnya bahasa bagi manusia kiranya tidak dapat diragukan lagi. Hal ini tidak saja dapat kita buktikan dengan menunjuk pemakaian bahasa dalam kehidupan sehari-hari, tetapi dapat juga kita buktikan dengan menunjuk banyaknya perhatian para ilmuan dan praktisi terhadap bahasa.

Bahasa Sasak adalah bahasa yang berkembang di pulau Lombok yang merupakan bagian dari wilayah Nusa Tenggara Barat. Bahasa Sasak adalah bahasa yang mempunyai ciri khas tersendiri yang digunakan oleh masyarakat Sasak yang terdiri atas dialek ngeno-ngene, meno-mene, meriak-meriku, kuto-kute, dan nggotonggete. Dalam penelitian ini, kajian difokuskan pada masayarakat desa Bagik Papan, kecamatan Pringgabaya Lombok timur yang menggunakan dialek ngeno-ngene dalam berinteraksi antar sesama. Masyarakat Sasak dalam berkomunikasi selalu mempergunakan ragam lisan. Ragam lisan inilah terdapat adanya kekhasan dan kekhususan tersebut. Salah satu bentuk kekhasan dan kekhususan itu adalah penggunaan kategori fatis.

Salah satu bentuk komunikasi yang penting adalah komunikasi fatis. Istilah komunikasi fatis dalam khasanah lingusitik Indonesia boleh dikatakan masih belum dikenal secara umum. Hal tersebut tampak pada minimnya literatur dan ulasan mengenai komunikasi fatis secara khusus.

Istilah komunikasi fatis yang diadopsi dari istilah phatic communion ini pertama kali diperkenalkan oleh Malinowski (1923) ${ }^{1}$ yaitu kegiatan atau perilaku berbicara yang berkaitan erat dengan kesopansantunan untuk menjaga sosiabilitas. Berawal dari konsep Mallinoski inilah, komunikasi fatis kemudian dikembangkan dan diterapkan dalam ilmu bahasa. Misalnya Leech $(1993)^{2}$ mengadopsi istilah phatic ini sebagai bagian dari prinsip kesopanan dalam bahasa. Demikian pula Kridalaksana (2008:114). ${ }^{3}$ mengadopsi istilah ini bahwa kategori-kategori fatis adalah kategori yang bertugas memulai, mempertahankan, atau mengukuhkan komunikasi antara pembicara dan kawan bicara

Kridalaksana (1990:120) ${ }^{4}$ mengatakan, bahwa kategori fatis merupakan penemuan baru dalam linguistik Indonesia yang keberadaannya tidak boleh diabaikan dalam deskriptif bahasa standar dan bahasa non-standar. Sebagai kajian baru dalam linguistik Indonesia, ungkapan fatis sangat banyak terdapat dalam kosa kata dan kalimat yang dipakai oleh masyarakat dalam bertutur kata. Fatis banyak ditemukan dalam bahasa lisan atau non-standar yang berbentuk dialog atau wacana, bahkan fatis menjadi ciri khas gaya bertutur lisan masyarakat. 
Kridalaksana $\quad(1990: 111)^{5}$ mengemukakan tiga fungsi fatis, yaitu memulai, mempertahankan, dan mengukuhkan pembicaraan antara pembicara dan kawan bicara. Selanjutnya Agustina (2007:185-194) ${ }^{6}$ mengemukakan tujuh fungsi fatis, yaitu memulai, menegaskan, mempertahankan, mematahkan, meyakinkan, mengukuhkan dan mengakhiri pembicaraan.

Komunikasi fatis menurut Leech (1993:224) ${ }^{7}$ merupakan maksim metalinguistik. Pertanyaan-pernyataan yang tidak informatif dalam komunikasi namun sangat penting dilakukan. Ia merumuskannya dalam bentuk negatif "hindarilah sikap diam' atau dalam bentuk negatif "berbicaralah terus" misalnya you've had a hair cut! (Kamu baru gunting rambut) layak diungkapkan karena menandakan penutur memperhatikan sesuatu yang dilihatnya pada lawan tutur meskipun telah melanggar aturan Maksim Kesepakatan, namun menghindari sikap diam dalam komunikasi dapat diberlakukan khusus dalam kategori Maksim Kesepakatan dan Maksim Simpati dengan asumsi bahwa mengembangkan kesamaan pengalaman sikap selalu mungkin menjadi sebuah tujuan ilokusi.

Bentuk komunikasi ini berupa sapaan, ucapan selamat, ungkapan basa-basi, permohonan maaf dan penghormatan mulai diabaikan. Hal tersebut menimbulkan adanya jarak satu dengan yang lainnya di dalam masyarakat. Dalam berinteraksi, masyarakat kurang mengetahui betapa pentingnya komunikasi fatis untuk menciptakan suasana yang penuh dengan saling pengertian.

Bahasa merupakan perkataanperkataan yang digunakan sebagai alat komunikasi untuk mengungkapkan perasaan dan pikiran-pikiran. Bahasa menunjukkan cerminan pribadi seseorang. Karakter watak, atau pribadi seseorang dapat diidentifikasi dari perkataan yang ia ucapkan. Penggunaan bahasa yang lemah lembut, sopan dan santun, sistematis, teratur, jelas, dan lugas mencerminkan pribadi penuturnya berbudi.

Kesantunan berbahasa menurut Chaer (2010: 110$)^{8}$ adalah upaya untuk menghindari konflik antara penutur dan lawan tuturnya di dalam proses komunikasi. Hal ini menunjukkan bahwa bahasa yang digunakan dalam proses komunikasi dapat membuat kita mempunyai banyak teman, disenangi tetapi juga sebaliknya.

Penggunaan ragam fatis misalnya dalam bentuk ungkapan, misalnya berupa (1) ucapan selamat, contoh "selamat pagi", "selamat jalan", "selamat belajar", (2) ucapan "terima kasih", (3) ucapan salam berupa, "assalamu alaikum dan wa'alaikummussalam" untuk memulai dan menutup interaksi ini sangat penting digunakan dalam mengungkapkan kesantunan (memertahankan jarak sosial), mengungkapkan kesantunan dan 
persahabatan (menghilangkan jarak sosial) kepada penutur yang berbedabeda baik dari status sosialnya maupun dengan melihat kondisi dan ragam bahasa apa yang digunakan, serta kapan dan bagaimana menggunakannya.

\section{METODE PENELITIAN}

Pengkajian terhadap bentuk Fatis bahasa Sasak sepengetahuan peneliti belum ada yang meneliti di samping kajian fatis relative baru, tetapi pengkajian bentuk fatis dalam bahasa lain sudah banyak yang melakukan baik di tesis, dan artikel. Dari pengamatan peneliti, terdapat beberapa penelitian yang relevan dengan penelitian ini antara lain.

Penelitian yang dilakukan Noviatari $^{9}$ berjudul Kategori Fatis Bahasa Minangkabau Kajian SintaksisSemantis (20006). Dalam kategori fatis bahasa Minangkabau, ditemui adanya kekhasan atau kekhususan. Kekhasan itu antara lain terlihat pada keragaman bentuk fatis, perilaku sintaksis dan perilaku semantiknya, dan eksistensi kehadirannya dalam kalimat. Di antara bentuk-bentuk fatis tersebut ada yang berfungsi mengubah jenis dan makna kalimat fungsi kehadirannya dalam kalimat, serta menjelaskan perubahan identitas satuan lingual kategori fatis menjadi satuan lingual lain
Penelitian lain yang mengkaji bahasa Fatis adalah Yusra ${ }^{10}$ menulis "analisis data dan pembahasan yang telah dilakukan terhadap analisis fatis bahasa Minangkabau dalam kaba "Rancak di Labuah" terdapat empat bentuk fatis yang terbagi kedalam 3 partikel, 8 paduan fatis, 6 kata fatis, dan 18 frasa fatis. Bentuk- bentuk fatis tersebut berfungsi untuk mengentarai kata, menegaskan cerita, memulai cerita, mengukuhkan cerita, dan meyakinkan cerita. Dari analisis data dan pembahasan yang telah dilakukan terhadap Dari analisis data dan pembahasan yang telah dilakukan terhadap analisis fatis bahasa Minangkabau dalam kaba "Rancak di Labuah" terdapat empat bentuk fatis yang terbagi kedalam 3 partikel, 8 paduan fatis, 6 kata fatis, dan 18 frasa fatis. Bentuk- bentuk fatis tersebut berfungsi untuk mengentarai kata, menegaskan cerita, memulai cerita, mengukuhkan cerita, dan meyakinkan cerita. Terdapat empat bentuk fatis yang terbagi kedalam 3 partikel, 8 paduan fatis, 6 kata fatis, dan 18 frasa fatis. Bentuk- bentuk fatis tersebut berfungsi untuk mengentarai kata, menegaskan cerita, memulai cerita, mengukuhkan cerita, dan meyakinkan cerita.

Dalam sebuah jurnal, Suhartini $(2010)^{11}$ mengkaji "Komunikasi Fatis Membangun Karakter Kesantunan Berbahasa" Bentuk komunikasi ini 
berupa sapaan, ucapan selamat, ungkapan basa-basi, permohonan maaf dan penghormatan mulai diabaikan. Hal tersebut menimbulkan adanya jarak satu dengan yang lainnya di dalam masyarakat. Dalam berinteraksi, masyarakat kurang mengetahui betapa pentingnya komunikasi fatis untuk menciptakan suasana yang penuh dengan saling pengertian.

Bahasa merupakan perkataan-perkataan yang digunakan sebagai alat komunikasi untuk mengungkapkan perasaan dan pikiran-pikiran. Bahasa menunjukkan cerminan pribadi seseorang. Karakter watak, atau pribadi seseorang dapat diidentifikasi dari perkataan yang ia ucapkan. Penggunaan bahasa yang lemah lembut, sopan dan santun, sistematis, teratur, jelas, dan lugas mencerminkan pribadi penuturnya berbudi. Bahasa memiliki peran sentral dalam perkembangan intelektual, sosial, dan emosional. Begitu pentingnya bahasa dalam kehidupan bermasyarakat, berbangsa, dan bernegara sehingga perlu suatu kebijakan yang berimplikasi pada pembinaan dan pembelajaran di lembaga pendidikan. Salah satu bentuk pembinaan yang dianggap strategis adalah pembelajaran bahasa Indonesia.

Penelitian ini menggunakan penelitian kualitatif dengan metode deskriptif, karena penelitian ini berusaha memberikan gambaran objektif tentang bentuk dan fungsi fatis yang terdapat dalam bahasa Sasak dialek ngeno-ngene desa Bagik Papan.. Data pada penelitian ini adalah tuturan bahasa Sasak dialek ngeno-ngene yang terdapat di desa Bagik Papan Pengumpulan data penelitian ini menggunakan teknik wawancara, transkripsi dan analisis teks.

\section{KATA FATIS DALAM BAHASA}

\section{SASAK}

\section{Fatis No}

Fatis No merupakan fatis yang berbentuk kata walaupun hanya terdiri atas dua huruf. Distribusi fatis No dalam kalimat hanya dapat mengisi posisi final. Fatis ini mempunyai makna sebagai berikut.

1.1 Menegaskan keberadaan tempat Contoh:

Inaq: Inoq, Leq embe taok panci? Inoq, di mana tempat panci?

Inoq : lek bawak rak no Di bawah rak

1.2 Menekankan kepastian

Contoh:

Amat : Jemak payu ke tetu de dateng? Besak jadi pasti kau datang?

Amin : tetu no!

Pasti donk!

\section{Fatis Ado/aro}

Kedua bentuk fatis ini digunakan dalam kalimat. Posisi yang dapat di isi oleh fatis ini adalah pada posisi awal, dan akhir dalam kalimat dan mempunyai makna sebagai berikut.

2.1 Menegaskan bantahan

Contoh:

Ado, ndek ku percaye side lekaq! 
'Ah, aku tidak percaya kamu pembohong!'

\subsection{Menghaluskan}

kekesalan/ketidaksenangan

Contoh:

Wah ku suruk ye sekolah, laguk ado ndek ne mele

'Sudah saya suruh dia sekolah, tapi (sayang sekali) ia tidak mau'

Ye tele kanak neke, ado wah

'Anak sekarang nakal (begitulah)'

\subsection{Menghaluskan sindiran}

Mun te ajum-ajum ye ado belek otak ne 'kalau kita sanjung-sanjung dia (pasti) besar kepalanya'

\section{Fatis Aile/idi gamak}

Fatis aile bervariasi dengan idi gamak inaq. Distribusi fatis ini dalam kalimat mengisi posisi medial atau final. Fungsi fatis aile/idi gamak dalam kalimat adalah

3.1 Menyatakan keheranan

Aile jeneng ne dedare sino

'Cantik seakali gadis itu'

Idi gamak bagus ne kelambinde

'Bagus sekali baju Anda'

3.2 Menegaskan ajakan basa basi

Laila tame be sekali lek bale meton

'Masuk/datanglah ke rumah sekali waktu'

\section{Fatis ndeh/ndi}

Fatis ndeh/ndi berdistribusi dalam kalimat pada posisi akhir saja sebagai penegasan atau pengukuhan seperti contoh berikut :

Papuq te ngendeng nyampu ndeh?

'Kakek minta jambunya ya?'

Udin paling pinter lek kelas ndi?

'Udin paling pintar di kelas ya?'

\section{Fatis ke}

Fatis ke tergolong dalam fatis yang berbentuk kata, walaupun seolaholah berbentuk partikel. Fatis ke dalam kalimat menempati posisi inisial dan final. Fatis ke umumnya bermakna

5.1 Menekankan kekesalan

$\mathrm{Ke}$, mate ante wah

'Mati kamu sekarang!'

5.2 Menekankan kuantitas suatu perbuatan

Tindok-tindok doang ke pegewaen de?

'Tidur aja pekerjaannya'

\section{Fatis yeh/ye/yoh/yok \\ Fatis yeh/ye bervariasi pemakaiannya dengan ye dan dapat menempati posisi awal dan final dalam kalimat. Fatis tersebut membentuk makna:}

\subsection{Menekankan ketidakpercayaan Yeh, masak iye doang paling toaq? \\ 'Masa sih dia saja yang paling tua?'}

\subsection{Menegaskan ketidaksetujuan}


Yeh, ndekne ngeno angkun dengan nemang aiq

'Bukan begitu cara orang memasukkan air'

\subsection{Menegaskan keheranan}

$Y$ e, ine doang jauk de?

'Ini saja yang dibawa?'

Iye doang nemang bola lek gawang ye

'Dia saja yang memsukkan bola ke gawang, (ya)?'

\section{PADUAN FATIS}

\section{Paduan aok aneh/aok ke}

Bentuk aok aneh/aok keh terdiri atas paduan aok dan aneh, aok dan keh karena itulah bentuk tersebut dikelompokkan ke dalam paduan fatis. Paduan fatis aok aneh, aok ke di dalam kalimat secara semantis bertugas. Aok aneh, aku doang be pade salahang 'Ya sudah, aku saja yang selalu disalahkan'

Aok ke, lalo wah laguk adeng-adeng 'Ya sudah, pergilah tetapi hati-hati'

\section{Paduan ne no, no ke}

Paduan fatis no ne dan no ke terbentuk dari fatis no ne dan no ke. Perbedaan pemakaian ne no dan no ke terletak pada penunjukan jarak antara dan objek tuturan itu sendiri. No ne untuk proksimal (dekat dari si penutur) no ke (agak jauh dari si penutur) di dalam kalimat paduan fatis ne no dan no ke dapat menduduki posisi awal dan final, dan mempunyai makna menekankan keraguan dan keingintahuan. Dalam konstruksi berikut kedua bentuk paduan fatis itu dapat saling menggantikan bila konstruksi tersebut tidak menggunakan demonstratif (i) ne dan (i) no atau (to) no dan (te) ne.

2.1 kumbeqne no kanak sino nangis kumbekne no kanak sine nangis 'Mengapa anak itu/ini menangis'

2.2 ye ngumbe kanak ino lek te ne ye ngumbe kanak ine lek to no 'Dia ngapain anak itu/ini di sana/di sini'

\section{GABUNGAN FATIS}

\section{Gabungan Fatis tene...ke}

Gabungan fatis tono...ke, dan tene...ke terdapat dalam kalimat majemuk menggunakan konstituen pola "negatif + positif" dan juga bermakna menegaskan maksud

Contoh:

Si wah ku beli te ne ku jual ke Si wah ku beli to no ku jual ke 'Yang sudah saya beli di sini/di sana saya jual gak!'

\section{Gabungan Fatis ino... ne}

Gabungan fatis ino... ne juga terdapat dalam kalimat majemuk dan menggunakan susunan konstituen pada "negatif+positif dan uga bermakna menegaskan maksud.

Contoh:

Si wah ku beli sino, ne ye!

'Yang sudah saya beli itu, ini!' 
3. Gabungan fatis ne...malik, no... malik

Gabungan fatis ne malik, no malik, malik...ye umumnya terdapat dalam kalimat majemuk yang bertentangan, yaitu pola positif dan negatif. Gabungan fatis ini menekankan makna menghaluskan paksaan.

Contoh:

Dendek malik suruk ye jauk awis ne, laguk ite wah ne jauk ye.

'Jangan suruh lagi dia membawa sabit ini, tapi kita sudah yang membawanya'

\section{Gabungan fatis Malik...wah}

Gabungan fatis milik...wah terdapat juga dalam kalimat majemuk dengan susunan klausa yang bertentangan, yaitu pola negatif + positif. Gabungan fatis tersebut juga menekankan makna menghaluskan paksaan. Gabungan fatis malik...wah (pola negatif+positif) objek atau keterangan terletak setelah klausa negatif karena fokus informasi, konstruksi tersebut terdapat pada klausa negatif.

Contoh:

Dendek malik sade iye ngangkat batu ino, lagug side wah

'Jangan lagi berikan dia mengangkat batu itu, tetapi kamu sudah'

\section{Gabungan fatis marak...mungkin}

Gabungan fatis marak...mungkin umumnya terdapat juga dalam kalimat negasi. Gabungan fatis tersebut umumnya bermakna menekankan keberadaan suatu fakta.

Contoh:

Ndek ne wah ngeraos cenge marak no mangkun dengan!

'Tidak pernak ia berbicara kotor seperti itu seperti orang yang lain!'

\section{SIMPULAN}

Analisis bentuk fatis bahasa Sasak khususnya (bahasa Sasak Desa Bagik Papan kecamatan Pringgabaya, Lombok Timur) dalam tulisan ini menyampaikan kajian awal, karena itu, kajian ini bersifat deskriptif pada aspek tertentu saja, yaitu fatis dalam bentuk kata, paduan fatis dan dari segi gabungan fatis itu sendiri.

Seperti yang telah dijelaskan pada bagian pengantar, bahwa bentuk fatis merupakan aspek bahasa yang menekankan pada sopan santun berkomunikasi yang bertujuan untuk menjaga dan mempertahankan sosiabilitas komunikasi, maka uraian yang terdapat dalam deskripsi fatis dalam bahasa Sasak ini pada umumnya untuk mempertegas atau mengukuhkan maksud, tujuan, penolakan, dan menghaluskan atau meminimalkan paksaan, suruhan serta larangan. 


\section{DAFTAR PUSTAKA}

${ }^{1}$ Malinowski, Bronislaw. 1923. "The Problem of Meaning in primitive languages" dalam The Meaning of Meaning (ed. Ogden dan Richards)

${ }^{2}$ Leech, Geofrey. 1993. Prinsip-Prinsip Pragmatik. Jakarta: Universitas Indonesia.

${ }^{3}$ Kridalaksana, Harimurti.2008. Kelas Kata dalam Bahasa Indonesia. Jakarta. Gramedia Pustaka Utama.

4 1990. Kelas Kata dalam Bahasa Indonesia. Jakarta: Gramedia.

5 Gramedia.

1990. Kelas Kata dalam Bahasa Indonesia. Jakarta:

${ }^{6}$ Agustina. 2004. "Ungkapan Fatis dalam Bahasa Minangkabau" dalam (Ungkapan Fatis dalam Pelbagai Bahasa) (Sutami Editor). Jakarta : pusat leksikologi dan leksikografi fakultas ilmu pengetahuan budaya universitas indonesia.

${ }^{7}$ Lihat Leech, Geofrey. 1993. Prinsip-Prinsip Pragmatik. Jakarta: Universitas Indonesia.

${ }^{8}$ Chaer, Abdul. 2010. Kesantunan Berbahasa. Jakarta: PT.Rineka Cipta.

${ }^{9}$ Novitari.2006" Kategori Fatis Bahasa Minangkabau : Kajian Sintaksis-Semantis ” dalam jurnal penelitian unpad.

${ }^{10}$ Yusra, Hasnawatil. Kategori Fatis Bahasa Minangkabau Dalam Kaba "Rancak Di Labuah"

${ }^{11}$ Suhartini "Komunikasi Fatis Membangun Karakter Kesantunan Berbahasa" dalam jurnal. http://sawali.info/2010/05/02/pendidikan-karakter-dan-hardiknas/ 